\title{
薬局ビッグデータを利用した住民の健康状態の推定
}

\author{
林譲, ${ }^{*}, a, b$ 齋藤充生, ${ }^{a, b}$ 矢島毅彦 ${ }^{a}$
}

\section{Estimation of the Health Status of People in the Vicinity of Pharmacies Using Pharmacy Big Data}

\author{
Yuzuru Hayashi, ${ }^{*, a, b}$ Mitsuo Saito, ${ }^{a, b}$ and Takehiko Yajima ${ }^{a}$
}

${ }^{a}$ Institute for Health Vigilance; Kamoshida-Building, 4-25-5 Tanashi-cho, Nishi-Tokyo, Tokyo 188-0011, Japan: and

${ }^{b}$ Faculty of Pharmaceutical Sciences, Teikyo Heisei University; 4-21-2 Nakano, Nakano-ku, Tokyo 164-8530, Japan.

(Received October 1, 2015)

\begin{abstract}
The purpose of this study was to propose a method for visualizing the patterns of the geographical propagation of influenza infection, and to elaborate parameters for the characterization of these patterns. First, a motion picture was prepared for the quotidian propagation of influenza infection in the Greater Tokyo Metropolitan area, which is considered a typical epidemic area for the 2012/2013 flu season. Second, hebdomadal recordings of patients with influenza infection in the 47 prefectures of Japan were grouped into 3 categories (1-peak, 2-peak, or multi-peak). The prefectures were arranged according to the weeks with the maximum number of patients, to examine variations in the temporal infection order of the districts among the flu seasons. These characteristics were analyzed using Cramer's coefficient of association and Spearman's rank correlation coefficient. Finally, the propagation of influenza infection was compared between urban and remote areas: the Greater Tokyo Metropolitan area and Tochigi prefecture. Regarding influenza virus infection, differences in population density, public transportation systems, and lifestyles between the urban and rural areas were found to lead to distinct endemic patterns of infection. Emphasis was placed on the so-called big data hubris.
\end{abstract}

Key words_ influenza propagation; epidemic; pandemic; pharmacy big data

\section{緒言}

感染症を地理情報と関連させることは，19世紀 の医師ジョン・スノーの研究以来，疫学の基本であ る. 現在では, 可視化・解析の方法として, GIS, SOARS など商業ベースのソフトウェアが多くあ り, 感染の度合いなどを入力すれば, 感染拡大の様 子を手軽にシミュレーションすることが可能であ

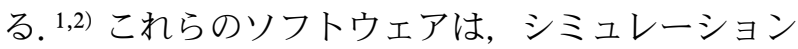
ゲームの制作にも使われていることは興味深い.

可視化・解析のソフトウェアだけではなく, ビッ グデータと呼ばれる情報源も溢れている. 内閣官房 及び経済産業省は, 産業構造や人口動態, 人の流れ などに関する情報を提供するシステム, 地域経済分 析システム $[\operatorname{RESAS}$ (リーサス) $]$ の提供を平成

$a$ 特定非営利活動法人ヘルスヴィジランス研究会 (テ188-0011 東京都西東京市田無町 4 丁目 25 番 5 号力 モシダビル 303 号室), $b$ 帝京平成大学薬学部 (T1648530 東京都中野区中野 4-21-2)

*e-mail: y.hayashi@thu.ac.jp

本総説は, 日本薬学会第 135 年会シンポジウム S44 で 発表した内容を中心に記述したものである。
27 年に開始した. ${ }^{3)}$ Google の検索データを用い て，インフルエンザの流行を推定しようとした試み もある. ${ }^{4}$

インフルエンザは, ヒトーヒト感染であるから, 人の動きと接触の度合いを設定すれば，インフルエ ンザの初期から最盛期, 終末への患者数の地域毎の 変化の様子を地図上で見ることができる，設定した 初期值（ヒトーヒト接触の度合いなど）の信憑性が 高ければ，得られた結果も信用できるかもしれな い. しかし，このような結果の真偽はどのように判 断すればよいのだろうか？ 入力をすれば，出力が かならず得られることは, 統計学の適用と似てい る。しかし，統計学では，その信憑性は，信頼区間 などで検証が可能である.

本稿は，シミュレーションやモデルを作成するの ではなく，インフルエンザ感染の伝播という現象を 観測する試みについて紹介する，最初に紹介するの は関東地方でのインフルエンザ伝播の動画であり, 約 300 店舗の薬局, それぞれで記録された患者数の 日間変動を地図上に示したものである。これはシ 
ミュレーションではなく，観測結果である，次に， 伝播の特徵を表すと考えられる要素について述べ る. 患者数の経時変化（グラフ）は，ピークの形が 一峰，二峰，多峰の場合があり，ここでは，これを 峰性と呼ぶ。峰性をシーズン毎に比べ，これが現れ る理由についても言及する。また，47 都道府県に おいて，どのシーズンでも感染が早い時期に起こる 県，又は，どのシーズンでも遅い県はあるのだろう か? この素朴な疑問にも答える. 最後に, 杤木県 でのインフルエンザ感染の伝播パターンを調ベ，東 京近辺の伝播パターンと比べる。「東京近郊と栃木 県では，人口密度，人の流れ(動線)が異なるので, 感染パターンも異なるだろう」とは，当然予測され る.シミュレーションでは，初期值を変えれば，こ の予測は容易に実現できるので，シミュレーション 自体からはその真偽は検証できない。本稿は，その 直接証拠を示す。

\section{方法}

動画は, 関東地方に点在する薬局 285 店舗におけ る 2012/2013 年インフルエンザシーズンの抗インフ ルエンザ薬使用量日間変動（2012 年 11 月 1 日から 2013 年 4 月 30 日）を解析し, 作成した. ${ }^{5)}$ 抗イン フルエンザ薬は, イナビル吸入粉末牏, リレンザ, タミフル（カプセル，ドライシロップ）であり，協 力薬局は，日本調剤株式会社，株式会社ピノキオ， クオール株式会社, 株式会社友愛メディカルであっ た. Figure 1 はこの動画からの抜粋である.

Figures 2-4 のグラフは, 総務省統計局, 厚生労 働省，国立感染症研究所などのホームページに収載 されているデータを利用した。

Figure 5 は，株式会社ピノキオから提供された デー夕を解析し，作成した。

\section{結果と考察}

Figure 1 は，ヘルスヴィジランス研究会（以下， ヘヴィ研）が作成した動画（http://he-vi.org/works /fluvideos.html) ${ }^{5)}$ からの抜粋である。へヴィ研の動 画では，動的なインフルエンザ感染の変化を日毎に 観測できる.

Figure 1 の円は，その中心が薬局の地図上の位置 であり，その半径がその薬局の患者数に比例するよ うに描いてある。.円の半径は日毎に変化するが,

Fig. 1 は，2012/12/14 から 2 週間おきに，インフ ルエンザ感染の経時変化を円で示している．これら

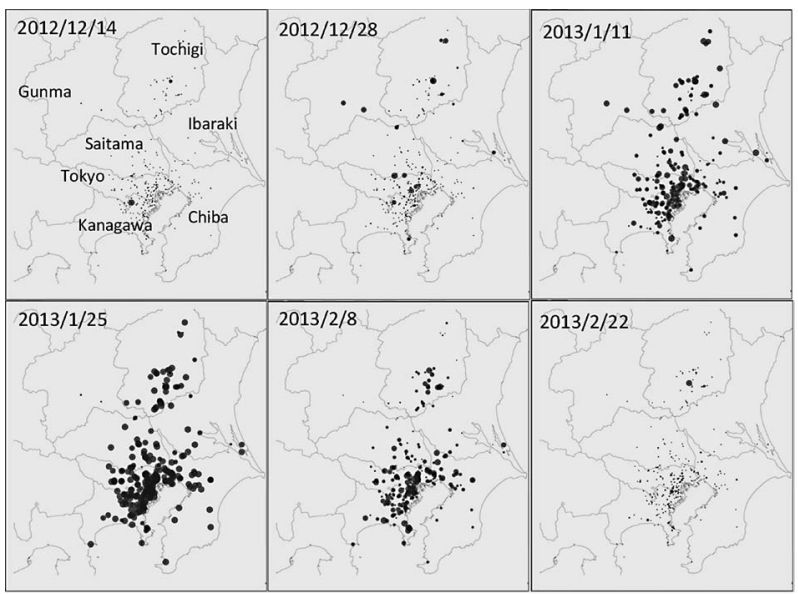

Fig. 1. Clips from the Motion Pictures of Influenza Propagation in Kanto Region, Provided by Institute for Health Vigilance

The original motion pictures show the quotidian changes in the number of flu patients (see http://he-vi.org/works/fluvideos.html).

6 個の図から, 関東地方における感染の拡大と終息 を大雑把ではあるが鳥瞰できる。栃木県と群馬県以 外の東京周辺地域の 2013/12/28 と 2013/1/11 を比 ベると（栃木県については後述），インフルエンザ 感染は, 東京都心部から始まり, 郊外へ伝播してい るように見える。

本稿では，Fig. 1（又は，へヴィ研の動画）が感 染の様子を忠実に表しているかどうかを考察する.

つまり, Fig. 1 の円の半径は 1 薬局の患者数である ので, 円の半径の合計は都県の相対的な患者数を近 似的に示していることを検証する.

インフルエンザは全数把握対象疾患ではなく, 定 点把握対象疾患である。しかし，Fig. 2 (A)にある ように定点把握の患者数と人口が強く相関 $(\mathrm{r}=$ 0.977）していることから, 定点把握患者数は全患 者数に比例していると容易に推測できる. しかし, これは偶然ではない. 国立感染症研究所は都道府県 の観測定点数を人口に比例するように設置したから である (2012 年度のデー夕からは, $\mathrm{r}=0.988)$ ，一 方, 都道府県別の薬局数は, 都道府県の人口と非常 に強い相関を示す $(r=0.987$; 散布図は, 文献5)に 掲載)。これは経済原理からすれば偶然ではないだ ろう. Figure 2(B) は, 関東地方の薬局数と人口の 相関を示す $(\mathrm{r}=0.985)$ 。これより, 都道府県の人 口に比例する数の薬局からのデー夕を収集すれば, 全患者数に比例する患者数が推定できると考えられ る. 

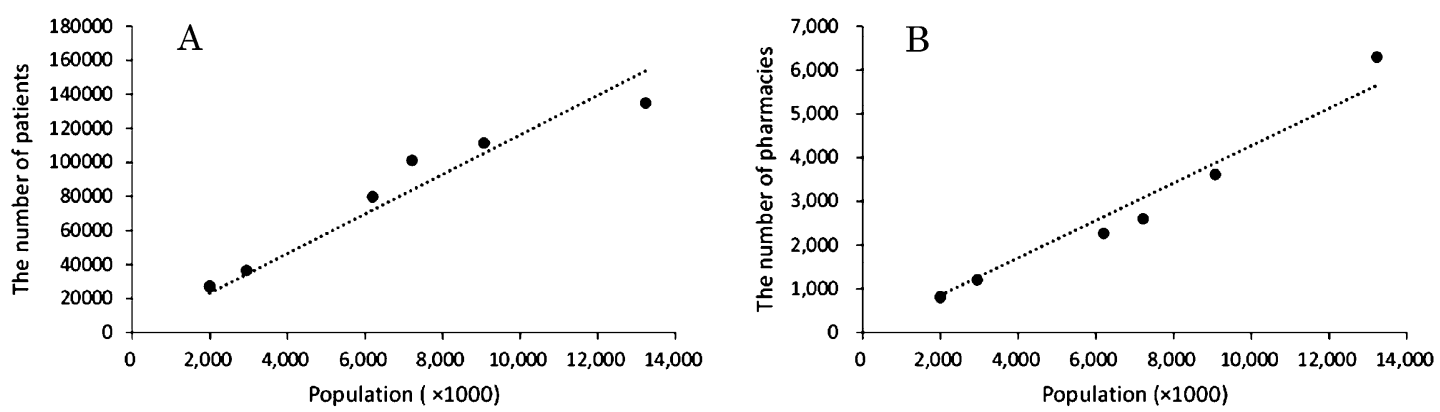

Fig. 2. Correlations between (A) Population and Patients Reported and (B) Population and Pharmacies in the Prefectures of the Greater Kanto Region

As the population, the number of pharmacies and that of patients are almost the same in Tochigi and Gunma prefectures, the plots of both the figures look less than seven which is the number of prefectures in the Kanto region. For analysis, the web pages of Ministry of Health, Labour and Welfare, Ministry of Internal Affairs and Communications and National Institute of Infectious Diseases were referred to.
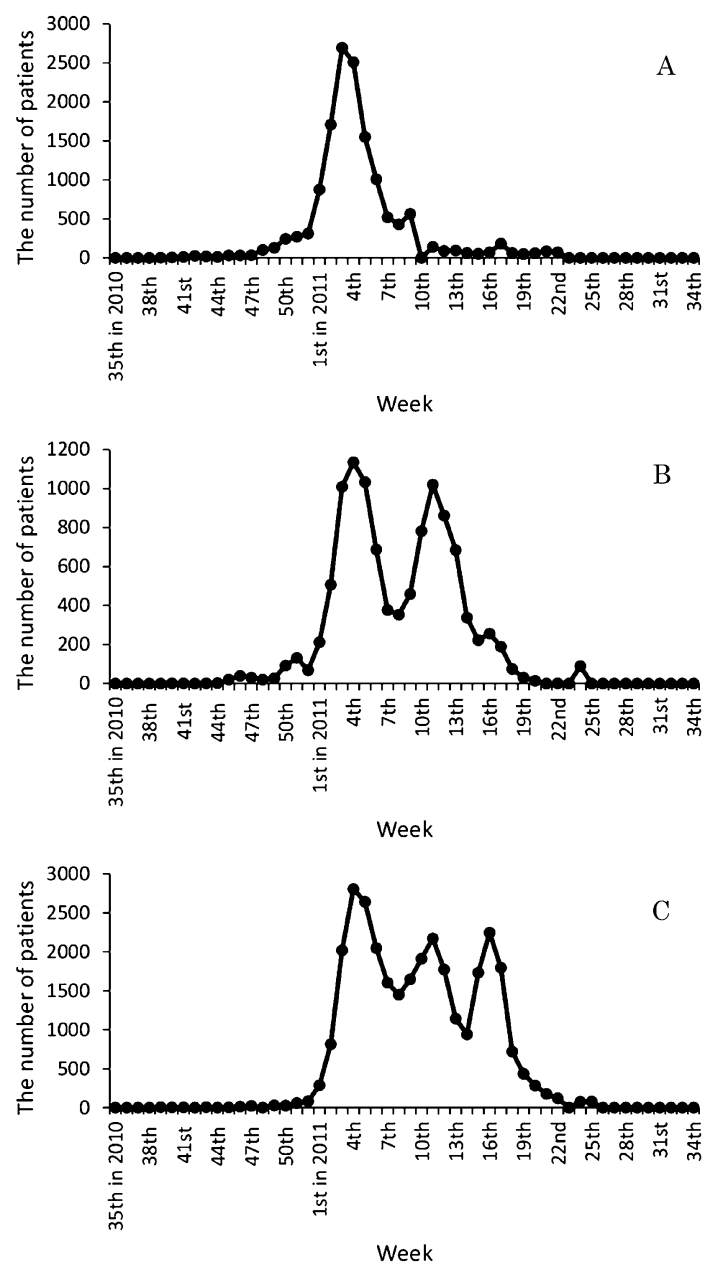

Fig. 3. Hebdomadal Changes in the Number of Influenza Patients Reported in (A) Miyagi, (B) Yamanashi and (C) Nagano Prefectures

For analysis, the web pages of National Institute of Infectious Diseases were referred to.

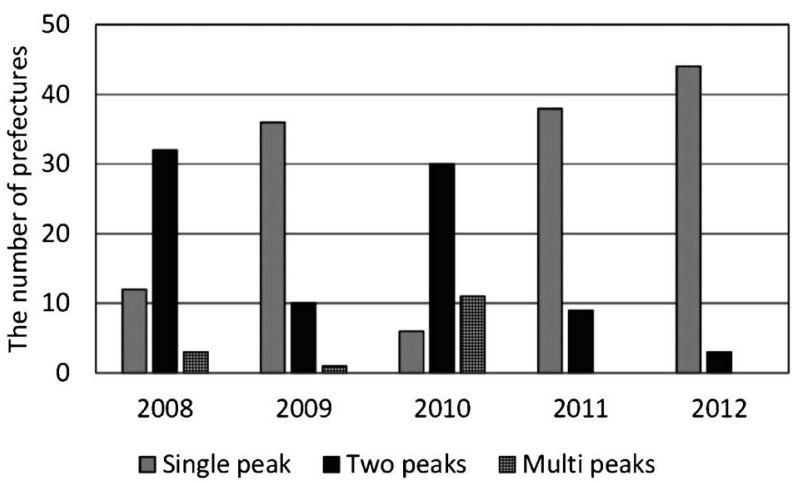

Fig. 4. Distribution of the Peak Patterns in Flu Seasons from 2008 to 2012

For analysis, the web pages of National Institute of Infectious Diseases were referred to.

Figure 1 の動画に表示してある都県毎の薬局数 （本研究の協力薬局の数）は, 東京都が 97, 千葉県 が 37 , 茨城県が 9 , 栃木県が 41 , 群馬県が 2 であ る.これらの薬局数と 7 都県の人口は強く相関する $(\mathrm{r}=0.859$; 散布図は文献 5 ) に掲載)。すると, 動画 は，全患者数を示していると考えられる. ${ }^{5)}$

インフルエンザ患者数の時系列パターンは，単純 な単峰性とは限らない。実際は，もう少し複雑な流 行パターンを示すので，この事実を紹介する。

Figure 3 は, 2010 年シーズンにおける典型的な 3 つのピークパターンである. A は単峰, B が二峰, Cが多峰のピークであり，それぞれ，宮城県，山梨 県, 長野県のパターンである。峰性を確定するため の規則としては, 分析化学で使われるピークバレー 比が 1.20 以上， 2 つ目のピークの高さが 1 番目の ピークの $20 \%$ 以上などを定めた。

Figure 4 は, 2008 年シーズンから 2012 年シーズ ンまでの各シーズンにおける峰性の分布である．注 
Table 1. Spearman's Rank-order Correlation Coefficients between Maximum-patient Days of the Prefectures in Japan

\begin{tabular}{c|c|c|c|c|c}
\hline \hline & $2008 / 2009$ & $2009 / 2010$ & $2010 / 2011$ & $2011 / 2012$ & $2012 / 2013$ \\
\hline $2008 / 2009$ & - & -0.041 & -0.116 & 0.055 & 0.166 \\
\hline $2009 / 2010$ & & - & -0.075 & -0.075 & 0.124 \\
\hline $2010 / 2011$ & & & - & -0.387 & 0.333 \\
\hline $2011 / 2012$ & & & & - & -0.297 \\
\hline $2012 / 2013$ & & & & & - \\
\hline
\end{tabular}

The rows and columns denote the flu seasons.

目すべきことは, シーズンによって，峰性の分布が 大きく異なっていることである. 2008 年シーズン と 2010 年シーズンは二峰性が圧倒的に多く, その 他のシーズンでは単峰性が圧倒的に多い. ${ }^{6)}$ クラ メールの連関係数は 0.49 であり, 峰性はシーズン 毎に統計的に区別できると結論してよいだろう.

峰性が生じる原因は, インフルエンザの A 型と $\mathrm{B}$ 型の発生時期の違いであることが, 最近の研究で 解明されつつある. A 型と B 型の流行にはラグが あることは既に分かっていた. 2001 年から 2004 年 の 3 シーズンでは, A 型が B 型より, 20 日から 1 カ月先行して流行したことが, 河合らにより報告

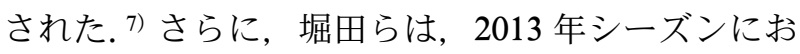
ける新潟の 1 薬局に来局した患者の調査により，A 型の流行ピークが 1 月であり, $\mathrm{B}$ 型のピークが 2 月

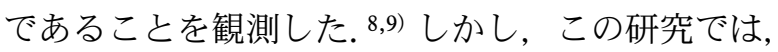
観測間隔が 1 カ月であり，インフルエンザの型の違 いと峰性の関係は明らかではなかった。

2015 年の薬学会年会において, 福岡らは, 2010 年と 2012 年の 2 シーズンに首都圈の日本調剤の薬 局に来局した患者の一部（それぞれ，2407人と 4211 人）からの聞き取り調査（薬歴に記載）の集

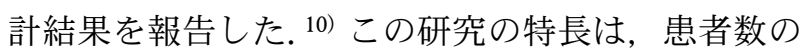
日間変動を多くの薬局（約 100 店舗）で追跡したこ とにある。彼らによれば, 2010 年シーズンでは,

$\mathrm{A}$ 型の感染ピークは 1 月 24 日, B 型のピークは 3 月9日であり, 全体として二峰性のピークが観測さ れた，一方， 2012 年シーズンでは， B 型の患者は 少なく, 全体として単峰性のピークが観測された. この結果は, Fig. 4 における 2010 年と 2012 年シー ズンの峰性の違いに一致することを示しており, 興 味深い. 同研究グループは医療薬学フォーラム 2015 において, 2010 年シーズンに調査した地域
(北海道, 東北, 関東, 中部, 近畿, 中国 - 四国, 九州）のほとんどでは， $\mathrm{A}$ 型と B 型の患者がとも に観測され二峰性を示すが, 東北地方は単峰性で A 型の患者が大部分を占めることを報告した. ${ }^{11}$

インフルエンザの感染パターンの特徵としては, 峰性以外に, 感染ピークの順位がある. あるシーズ ンにおける 47 都道府県のピーク週を順番に並べ, 他のシーズンについても同様に並べ，これらの相関 係数（スピアマンの順位相関係数と呼ぶ）を求めた のが, Table 1 である，例えば, 2008 年シーズンと 2009 年シーズン間のスピアマンの順位相関係数は -0.041 であり, 2008 年シーズンの順位と 2009 年 の順位はバラバラであることが分かる. ${ }^{6}$ 同様に他 の組み合わせにおいても，ほとんどの場合，スピア マンの順位相関係数は小さく, 感染ピーク週はシー ズン毎にランダムであると結論できる. 事実, 北海 道は 2009 年シーズンでは 1 位であるが, 2010 年 シーズンでは 38 位であった。このランダム性は, 東京都の行政区画（区，市）のインフルエンザ感染 においても観測され（Table 2)，横浜市の行政区画

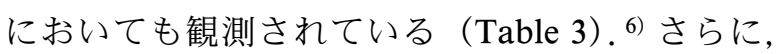
東京近辺の薬局においても, このランダム性は観測 された. ${ }^{12)}$ 地区の感染順序がランダムであることの 理由は, 今のところ不明であるが, 日本でのインフ ルエンザ感染の 1 つの特性として挙げてよいだろう.

インフルエンザ感染の伝播経路, 峰性, 順位と考 察を進めてきた. 最後に, もう一度伝播経路をとり 上げる. 東京近辺では, 人々が行政区画を跨いで, 一様に密に居住し, 電車, バスなどの路線が縦横に 走っているため, 人の往来が地理的に連続してい る. 一方, 栃木県の人口密度は東京都に比べ約 1 / 20 であり, Fig. 5 の地区 A-J の居住地域間での人 の往来はそれほど密ではない。 そう考えると, 地域 
Table 2. Spearman's Rank-order Correlation Coefficients between Maximum-patient Days of the Wards in Tokyo

\begin{tabular}{c|c|c|c|c|c}
\hline \hline & $2008 / 2009$ & $2009 / 2010$ & $2010 / 2011$ & $2011 / 2012$ & $2012 / 2013$ \\
\hline $2008 / 2009$ & - & -0.160 & 0.377 & -0.067 & -0.018 \\
\hline $2009 / 2010$ & & - & 0.128 & 0.275 & -0.377 \\
\hline $2010 / 2011$ & & & - & -0.026 & -0.038 \\
\hline $2011 / 2012$ & & & & - & -0.173 \\
\hline $2012 / 2013$ & & & & & - \\
\hline
\end{tabular}

The rows and columns denote the flu seasons.

Table 3. Spearman's Rank-order Correlation Coefficients between Maximum-patient Days of the Wards in Yokohama

\begin{tabular}{c|c|c|c|c|c}
\hline \hline & $2008 / 2009$ & $2009 / 2010$ & $2010 / 2011$ & $2011 / 2012$ & $2012 / 2013$ \\
\hline $2008 / 2009$ & - & -0.304 & -0.306 & 0.347 & -0.078 \\
\hline $2009 / 2010$ & & - & -0.031 & -0.392 & 0.467 \\
\hline $2010 / 2011$ & & & - & -0.124 & 0.111 \\
\hline $2011 / 2012$ & & & & - & -0.246 \\
\hline $2012 / 2013$ & & & & & - \\
\hline
\end{tabular}

The rows and columns denote the flu seasons.

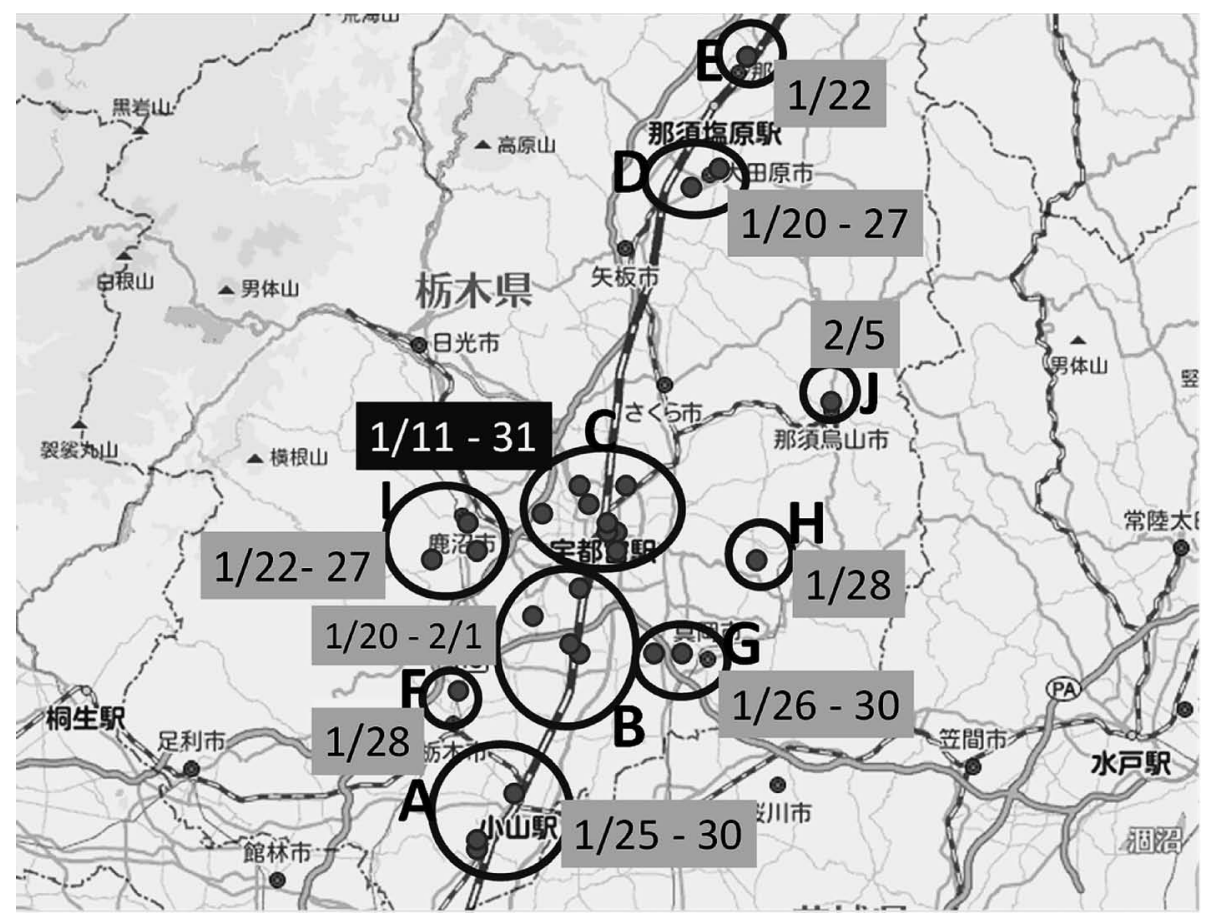

Fig. 5. Periods of Influenza Infection Peak Days in Some Regions of Tochigi Prefecture in 2012/2013 Season

The dates or periods of the flu peak dates are shown near the regions marked with large closed circles. The locations of the participating pharmacies are indicated with small filled circles. A: Oyama; B: Shimotsuke; C: Utsunomiya; D: Otawara; E: Nasu-Shiobara; F: Tsuga in Tochigi; G: Moka; H: Ichikai in Hagagun; I: Kanuma; J: Nasu-Karasuyama. 
A-J では，東京近辺とは異なるインフルエンザの 感染パターンの発見を期待できる.

Figure 5 は, 小さい黒丸が薬局の位置（26店 舗)，黒丸を含む大きな丸が居住地域 A-J である. 日付は, 2012/2013 年シーズンにおける 26 薬局の 抗インフルエンザ薬（タミフル，リレンザ，イナビ ル）使用量の日間変動から求めた感染ピーク日（使 用量時系列の重心）である. ${ }^{13)}$ 宇都宮駅周辺（C, 8 店舗）の感染ピーク日は $1 / 11$ から $1 / 31$ の間にある が，周辺地域の感染ピークは，往々にしてこれより も遅い，例えば，小山駅周辺（A，3 店舗）は $1 / 25-$ 30 であり，下野市（B，4 店舗）は 1/20-2/1 であ り，大田原市 $(\mathrm{D}, 2$ 店舗) は 1/20-27 であり, 那 須塩原市 (E，1 店舗) は 1/22 である。この結果は, 杤木県では，宇都宮周辺の住民が最初にインフルエ ンザに感染し，その後に周辺地域の住民が感染する ことを示唆している.この推論は, 2011 年シーズ ンと 2013 年シーズンで同様の観測を行い， 2012 年 シーズンとほぼ同じ結果が得られたことから支持さ れた。

杤木県の 3 シーズン（2011, 2012, 2013 年）の感 染ピーク日のスピアマンの順位相関係数は，大きく ても 0.2 であり, 感染ピーク日はシーズン毎にラン ダムであると言える. ${ }^{13)}$ それにもかかわらず，宇都 宮から周辺地域への伝播経路が観測されたことは, 偶然ではないだろう。実際に，栃木県の住民は，宇 都宮駅から新幹線などで東京に行くことが多い.

Figure 1 の動画からは，東京都心部と宇都宮駅周辺 はほぼ同じ時期に感染が始まり，周辺の地域へと広 がっているように見える。宇都宮市以外の住民は, 宇都宮駅に行くほうが, 他の地域へ行くよりも, 頻 繁であると仮定すると, 宇都宮駅周辺から他の地域 ヘインフルエンザが伝播すると考えるのが自然であ る. 少なくとも, Fig. 5 からは，そう思える．もう 一度強調すると, Fig. 5 は，患者数時系列の重心を 図に表記したものであり，解釈ではなく，観測を示 したものである.

\section{結論}

本稿は，インフルエンザの伝播について，決して 十分とは言えないが，筆者らがこれまでに提案して きた伝播の特徵，つまり伝播の地理的経路，感染時 系列のパターン (峰性) と観測点の感染順序を紹介 したものである，伝播経路の解明は，パンデミッ
ク，バイオテロなどを考慮すると，社会的には喫緊 の問題であり，その利用価值は高い. 残念ながら， 感染症の地理的伝播を研究する学問的な方法論は確 立されているとは言えない現状であり, 研究者は暗 中を手探りで進んでいる，本稿の内容も，日本にお けるインフルエンザ伝播の特徵を示していると断言 するものではなく，一試論である，方法論の確立に ついては, 将来の研究を待ちたい.

謝辞本研究をお手伝い頂いた帝京平成大学薬 学部卒研生, 日野 航, 杉山 諒, 高橋尚輝の三君 に感謝する.

利益相反＼cjkstart開示すべき利益相反はない.

\section{REFERENCES}

1) Carroll L. N., Au A. P., Detwiler L. T., Fu T.-C., Painter I. S., Abernethy N. F., $J$. Biomed. Inform., 51, 287-298 (2014) .

2 ) Nsoesie E. O., Brownstein J. S., Ramakrishnan N., Marathe M. V., Influenza Other Respir. Viruses., 8, 309-316 (2014).

3) RESAS: 〈https://resas.go.jp/ $/$, cited $24 \mathrm{Au}-$ gust, 2015.

4) Lazer D., Kennedy R., King G., Vespignani A., Science, 343, 1203-1205 (2014).

5) Saito M., Hayashi Y., Yajima T., Jpn. J. Drug Inform., 17, 94-99 (2015).

6) Saito M., Sugiyama R., Hayashi Y., Yajima T., Abstracts of papers, the 135th Annual Meeting of the Pharmaceutical Society of Japan, Kobe, March 2015, No. 4, p. 135.

7) Kawai N., Ikematsu H., Iwaki N., Maeda T., Kawashima T., Tanaka O., Kondo K., Horiniwa K., Harada T., Takahashi T., Kanazawa H., Sato I., Mitsuoka S., Yoshimura M., Tamai Y., Okayama K., Miyaji K., Matsuura N., Tomita S., Fujikawa M., Takayasu K., Tsuchimoto T., Mise N., Nagai T., Kachi T., Kimura T., Koshino Y., Makino T., Kawamura K., Shigematsu T., Hirotsu N., Kunishima O., Goto Y., Kashiwagi S., Japan Medical Journal, 4252, 21-27 (2005).

8) Hotta M., Ichiyanagi I., Oyo Yakuri, 86, 9396 (2014).

9) Hotta M., Ichiyanagi I., Suzuki N., Oyo 
Yakuri, 88, 53-56 (2015).

10) Fukuoka K., Nishida S., Saito M., Hayashi Y., Yajima T., Abstracts of papers, the 135th Annual Meeting of the Pharmaceutical Society of Japan, Kobe, March 2015, No. 4, p. 136.

11) Fukuoka K., Nishida S., Saito M., Hayashi Y., Yajima T., Abstracts of papers, the 23rd Clinical Pharmacy Symposium/Clinical Pharmacy Forum of the Pharmaceutical Society of Japan, Nagoya, July 2015, p. 338.
12) Nishida S., Fukuoka K., Hino W., Saito M., Hayashi Y., Yajima T., Abstracts of papers, the 58th Kanto Branch Meeting of the Pharmaceutical Society of Japan, Machida, October 2014, p. 290.

13) Saito M., Sugiyama R., Kondo S., Tanaka N., Hayashi Y., Yajima T., Abstracts of papers, the 135th Annual Meeting of the Pharmaceutical Society of Japan, Kobe, March 2015, No. 4, p. 136. 